\title{
Determinants of Rice Import Demand in Nigeria
}

\section{${ }^{{ }^{* 1} Y U S U F, ~ W A ; ~}{ }^{1,3}$ YUSUF, SA; ${ }^{2}$ ADESOPE, AAA; ${ }^{3}$ ADEBAYO, OZ}

\author{
${ }^{*}$ Department of Economics, Nile University of Nigeria, FCT Abuja \\ ${ }^{2}$ Forestry Research Institute of Nigeria (FRIN), Jericho, Ibadan \\ ${ }^{3}$ Department of Agricultural Economic, University of Ibadan, Nigeria \\ ${ }^{*}$ Corresponding Author Email: ywasiu40@gmail.com
}

\begin{abstract}
Primarily, the study examined the determinants of rice import demand in Nigeria by assessing the short run and long run dynamic model relationships among the determinants, trends and extent of causality among per capita income, population, exchange rate and price of rice imports were equally examined, using data obtained from the Central Bank of Nigeria (CBN) and National Bureau of statistics (NBS) over the period 1961 to 2013. Data obtained showed the perceived determinants of imports demand for rice in Nigeria were local rice production, rice import price, rice consumption, per capita income, and exchange rate, price of local rice, domestic stock variation, maize price, meat price and demographic development. The short run dynamic model result showed that rice consumption, price of meat, price of maize, local rice quantity, demography development and stock variance are statistically significant at $5 \%$. The significance of the coefficient of the error correction term confirmed the appropriateness of the error correction approach which also showed that ignoring the long run relationship is detrimental. The result however, revealed that rice import demand increases significantly with increasing rice consumption, increasing price of meat, increasing price of maize (keeping that for imported rice unchanged) and increasing demography development. Rice import price, per capita income, price of local rice and exchange rate had no significant effects on rice import demand. The study therefore recommends that locally-produced rice should be intensively improved.
\end{abstract}

\section{DOI: https://dx.doi.org/10.4314/jasem.v24i5.30}

Copyright: Copyright (C) 2020 Yusuf et al. This is an open access article distributed under the Creative Commons Attribution License (CCL), which permits unrestricted use, distribution, and reproduction in any medium, provided the original work is properly cited.

Dates: Received: 10 March 2020; Revised: 29 April 2020; Accepted: 28 May 2020

Keywords: demography, determinants, Error correction mechanism, rice import demand

Rice forms a significant portion of food consumed in most households in Nigeria, it has remained one of the most important cereals and staple food stuffs in Nigeria (Akpan et al., 2014; and Erhabor and Ojogho, 2011). Isa et al., 2013 observed that rice is one of the few food items whose consumption has no cultural, religious, ethnic or geographical boundary in Nigeria, and constitutes one of the major staples, which can provide a nation's population with the nationally required food security minimum of 2,400 calories per person per day (Bamidele et al., 2010). The study also asserted that the demand for rice has been increasing in Nigeria at a much faster rate than domestic production and more than in any other African countries since mid-1970s due to its increasing contribution to the per capita calorie consumption of Nigerians. In some countries, the per capita consumption of rice is estimated at more than $100 \mathrm{~kg} /$ year. Estimates from FAO agricultural production database for Nigeria shows that, the gap between domestic demand of rice for food (as against feed and other uses) has widened since the late 1990s. Unfortunately, the domestic production of rice has not met the demand which led to food shortage problems. In a bid to address the demand/supply gap for rice, the government at various times had adopted and applied policies and programmes such as rice importation to supplement the local production which has continue to drain the country's hard earned foreign exchange earnings. With a population estimate of 174,507,539 persons and population growth rate of $2.54 \%$, Nigeria happens to be not only the leading producer of rice in West Africa, but also among the leading importers of the commodity. Although endowed with a strong agricultural and natural resources base as well as favourable climatic conditions for agricultural production, an amount of about 1 billion is spent daily by Nigeria on importation of rice (Abubakar, 2013). FAO (2008) estimate also indicates that Nigerian rice import increases from 1876 tonnes in 1980 to 2630 million tonnes in 2002 . The total import also stood at 1.9 million tonnes in 2003 (Central Bank of Nigeria (CBN), 2004). The Federal Government spent $\$ 2.41$ billion on rice importation between January 2012 and May 2015 (Central Bank of Nigeria, 2015). Between 2010 and 2014, Nigeria imported about 10,876,148.3 tonnes of rice. All these have a huge financial implication on the economy and the development of the domestic potentials in the subsector. Rice imports have affected the domestic production and marketing of Nigeria's local rice as a result of decrease in the demand of local rice by Nigerians. As a response to the prevailing rice supply deficit situation in Nigeria, successive Nigerian governments intervened in the rice sector through the establishment of parastatals and policies since 1970; 
among which were Agricultural Development Projects (ADP) 1975, Operation Feed the Nation (OFN) in 1976, the River Basin Development Authority (RBDA) 1977, the Structural Adjustment Programmes (SAP) 1986, and the Presidential Initiative on Increased Rice Production, Processing and Export (PIIRPPE) 2001. The emergence of the VEETEE rice company in 2004 was another way to boost local rice production in Nigeria. The company has the facility for polishing rice, which means high quality of local rice (Bamidele, et al., 2010); all these were aimed at encouraging and boosting local rice production. However, in spite of these numerous programmes rice importation continue to increase because rice has become a strategic commodity in the Nigerian economy, therefore there is pertinent need to empirically assess the determinant of rice import demand in Nigeria.

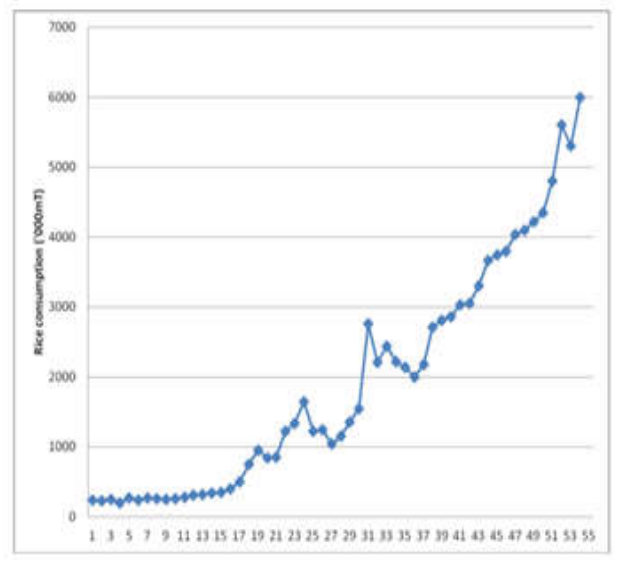

Fig 1: Rice Consumption Trend 1960(T =1) to $2013(\mathrm{~T}=54)$

Though rice contributes a significant proportion of the food requirements of the population, production capacity is far below the national requirements for rice (Wudiri and Fatoba, 1992; and Ladebo, 1999). Nigeria is currently the largest rice importer in the world. As demand for rice rises in Nigeria, it is clear that production has failed to keep pace while the gap has been bridged by growing imports. Rising consumer preference for rice has increased demand at a faster rate than population growth. According to Oluyemisi 2013, per capita production has remained stagnant at about $28 \mathrm{~kg} /$ person since 1990. This is in sharp contrast to Mali, Ghana and Senegal where it has doubled or even tripled over the same period. As a result, while Nigeria contributes the most to total production in the region, its share has declined by 10 percentage points since the early 1990 s, from 47.7 to 37.5 percent. The Nigerian rice economy has lagged behind these three countries and others in the region.However, in response to the continuing demand for imported rice, the Nigerian government has embarked on several policy reforms, ranging from quantity restriction, ban, tariff, and trade liberalization. Similarly, prior to1997, the government strategy to maintain rice self-sufficiency level has been through direct support to producers by providing fertilizer subsidies to farmers and consumers through price controls, now having complied with WTO trade agreements, these subsidies have been dismantled, and the country faces new challenges of sustaining a viable rice industry to meet national self-sufficiency targets. Over the years, the country has continued to depend on importation of rice to meet the demand and preference for her teeming population. Available study (Emodi and Madukwe, 2011) revealed that Nigeria is the largest importer of rice in the world. Although increase in rice imports for Nigeria is of greater concern to the government and rice producers in the country, however, only a few studies has been carried out on the determinants of rice imports in Nigeria, Okeowo (2016) worked on Aggregate Import Demand Analysis ,of Rice in Nigeria, Sunday et al 2015 worked on Roles of Political and Economic Environments on Agricultural Commodity Import Demand in Developing Economy: A Case Study of Rice SubSector in Nigeria, Ogundele (2007) worked on assessing trade liberalization and import demand for rice in Nigeria while Nkang et al. (2006) worked on a study on "rice production, imports and food security in Nigeria. Also some efforts have been made so far at the national level, which have placed emphasis on identifying the determinant of aggregate imports in Nigeria for example Determinants of Nigeria's NonOil Import Demand by Aladejare and Abdulwahab (2014), Determinants of food imports demand and policy shift in Nigeria 1960-1998 by Udoh et al. (2001).

Several investigations carried out so far into identifying the determinants of rice and other food imports in Nigeria have gone beyond simple associations by covering different variables including local production (output) of the imported commodity, total import value, external reserves, exchange rate, and industrial capacity utilization, among others. Worthy of note are studies on determinant of rice import demand; roles of political and economic environments on rice import demand by Sunday et al., 2016, effects of various trade policy instruments such as tariff, import restrictions, outright ban on rice import and other determinants on the import demand for rice in Nigeria by Ogundele 2007, rice production, imports and food security in Nigeria by Nkang et al.; 2006. However, variables such as Price of rice complement, price of rice substitute, domestic stock variation and rice consumption were not included in all the past studies examined. Hence, the need to critically assess the determinants of rice import demand in Nigeria.

\section{MATERIALS AND METHODS}

Data for this study were secondary in nature and were sourced from Food and Agriculture Organization (FAO) and World Development Indicator (WDI). Data on volume and value of rice import, volume and value 
of local rice, rice consumption, price of maize and meat and stock variance were gathered from FAO (FAOSTAT), while data on per capita income, exchange rate, consumer price index and population related data were gathered from development indicators of the World Bank. Also, the study employed analytical techniques such as descriptive statistics, unit root test, co-integration, error correction mechanism and granger causality. This study also pattern its model in line with Shehu and Aliyu (2007) which happen to be the most appropriate for this study. They employed the simple import demand model as developed by Khan (1974). This involves a cointegration and error correction modelling, using the Ordinary Least Squares regression (OLS) estimation technique, which were based on the simple linear relationship between rice imports as dependent variables and rice import price, per capita income, exchange rate, volume of local rice, price of local rice, total rice consumption, domestic stock variation, price of pseudo substitute, price of complement, demographic development and consumer price index as independent variables; the model specified a linear relationship between rice imports quantity (RMQ) as dependent variable, and Rice Import Price (RMP), Rice Consumption (RC), Per Capita Income (PCI), Exchange-Rate (EXG), Local Rice quantity (LRQ), Price of Local Rice (LRP), Domestic Stock Variation (DSV),Maize Price (MaP), Meat Price (MeP) and Demographic Development (DD). The functional rice import demand can be specified as;

$\mathrm{RMQ}=\mathrm{f}(\mathrm{RMP}, \mathrm{RC}, \mathrm{PCI}, \mathrm{EXG}, \mathrm{LRQ}, \mathrm{LRP}, \mathrm{DSV}$, $\mathrm{MaP}, \mathrm{MeP}, \mathrm{DD})$ (1)

Where: RMQ $=$ Rice Imports Quantity; $\mathrm{RC}=$ Rice Consumption; PCI = Per Capita Income; $\mathrm{EXG}=$ Real Exchange-Rate; LRQ = Local Rice quantity; LRP = Local Rice Price; DSV = Domestic Stock Variation; $\mathrm{MaP}=$ Maize Price; $\mathrm{MeP}=$ Meat Price; $\mathrm{DD}=$ Demography Development Period, and $\mathrm{f}=$ functional notation. While "U" (the error term) was introduced to take care of variables not included in the model but affect rice import, equation (1) transforms to:

f(RMP, RC, PCI, EXG, LRQ, LRP, DSV, MaP, MeP, DD)

$\mathrm{RMQ}=\beta \mathrm{o}+\beta_{1} \mathrm{RMP}+\beta_{2} \mathrm{RC}+\beta_{3} \mathrm{PCI}+\beta_{4} \mathrm{EXG}+$ $\beta_{5} \mathrm{LRQ}+\beta_{6} \mathrm{LRP}+\beta_{7} \mathrm{DSV}+\beta_{8} \mathrm{MaP}+\beta_{9} \mathrm{MeP}+$ $\beta_{10} \mathrm{DD}+\mathrm{U}$

The dynamic model of equation (2) after expressing same in log-linear form as supported by Thursby and Thursby (1984) is specified as;

$l_{n} \mathrm{RMQ}=\beta \mathrm{o}+\beta_{1} l_{n} \mathrm{RMP}+\beta_{2} l_{n} \mathrm{RC}+\beta_{3} l_{n} \mathrm{PCI}+$ $\beta_{4} l_{n} \mathrm{EXG}+\beta_{5} l_{n} \mathrm{LRQ}+\beta_{6} l_{n} \mathrm{LRP}+\beta_{7} l_{n} \mathrm{DSV}+$ $\beta_{8} l_{n} \mathrm{MaP}+\beta_{9} l_{n} \mathrm{MeP}+\beta_{10} l_{n} \mathrm{DD}+\mathrm{U}$ $\beta$ o, $\beta_{1}, \beta_{2}, \beta_{3}, \beta_{4}, \beta_{5}, \beta_{6}, \beta_{7}, \beta_{8}, \beta_{9}$ and $\beta_{10}$ are the elasticities of Rice Import Price (RMP), Rice Consumption (RC), Per Capita Income (PCI), Exchange-Rate (EXG), Local Rice quantity (LRQ), Price of Local Rice (LRP), Domestic Stock Variation (DSV), Maize Price (MaP), Meat Price (MeP), and Demographic Development (DD). The study then sets the apriori expectation as $\beta_{1}, \beta_{4}, \beta_{5}, \beta_{6}, \beta_{7}, \beta_{9}<0 ; \beta_{2}, \beta_{3}$, $\beta_{8}, \beta_{10},>0$; and $\beta_{0}<=0$

Furthermore, the empirical section examined the stationary conditions of the data by applying the augmented Dickey-Fuller (1979) and the PhillipsPerron (1988) test. Dickey and Fuller stretched the procedure of their test proposing an augmented version that contained more lagged term of endogenous variable to eradicate the autocorrelation.

$\Delta \mathrm{Yt}=\alpha_{1}+\alpha_{2} \mathrm{t}+\delta y_{t-1}+\sum_{i}^{m} \theta \Delta y_{t-1}+\varepsilon_{t}$

$\mathrm{Yt}=$ time series aggregate to be tested, $\mathrm{t}=$ time or trend variable, $\Delta \mathrm{yt}=\left(\mathrm{Yt}_{-1}-\mathrm{Yt}_{-2}\right), \Delta \mathrm{yt}_{-2}=\left(\mathrm{Yt}_{-2}-\mathrm{Yt}_{-3}\right)$ etc, $\varepsilon_{t}=$ pure white noise error term, $\Delta=$ first deference operator, $\alpha_{1}=$ constant term, $\alpha_{2}=$ trend parameter, $\delta=$ the parameter to be tested $\sum_{i}^{m} \theta \Delta y_{t-1}=\mathrm{ADF}$ term; it removes any possible autocorrelation between $\Delta \mathrm{yt}$ and $\varepsilon_{t}$

Equation (4) is the bench mark for the unit root model. Emphasis here was on the behaviour of the constant $\left(\alpha_{1}\right)$ and time parameter $\left(\alpha_{2}\right)$; they will provide information for the specification. Where both $\alpha_{1}$ and $\alpha_{2}$ are significant, then equation (4) will be justified as the true model. However, in a situation where $\alpha_{2}$ is insignificant but $\alpha_{1}$ is significant; equation (4) transforms to;

$\Delta \mathrm{yt}=\alpha_{1}+\delta y_{t-1}+\sum_{i-1}^{m} \theta \Delta y_{t=1}+\varepsilon_{t}$

If however the situation is the other way round, that is; $\alpha_{1}$ is insignificant but $\alpha_{2}$ is significant; equation (4) transforms to;

$\Delta \mathrm{yt}=\alpha_{2} \mathrm{t}+\delta y_{t-1}+\sum_{i-1}^{m} \theta \Delta y_{t=1}+\varepsilon_{t}$

However, given that it has been established in the econometric modeling that trend is stochastic, we will here be faced with the decision to remove $\alpha_{2}$ t from the model and trend becomes insignificant; when effected equation (6) reduces to;

$\Delta \mathrm{yt}=\delta y_{t-1}+\sum_{i-1}^{m} \theta \Delta y_{t=1}+\varepsilon_{t}$

Equation (7) becomes the true general model for unit root test

Co-integration test was applied to find out the long run relationship between the used variables. It becomes a necessary requirement in any economic model using 
non-stationary time series data. When non-stationary variables do not show co-integration then it would show spurious regression and econometric work becomes almost meaningless. On the other hand, if the stochastic trends do cancel, then we have cointegration which will then necessitate an error correction model (ECM). The ECM has the advantage of including both long-run and short-run information of the model.

Thus, $y, x \sim I(1)$

Where $\mathrm{Y}=$ rice import (dependent variable), $\mathrm{X}=$ vector of explanatory variables.

$\mathrm{Yt}=\alpha_{\mathrm{o}}+\alpha_{1} \mathrm{Xt}+\mathrm{Ut}$

Linearly

$\widetilde{U} t=\left(Y t-\tilde{\alpha}_{\mathrm{o}}-\tilde{\alpha}_{1} \mathrm{Xt}\right)$

Cointegration exist if $\widetilde{\mathrm{U}} \mathrm{t} \sim \mathrm{I}(0)$

In the event of a long run relationship among the variables, equation (3) transforms into an error correction model specified as:

$\mathrm{RMQ}=\beta_{\mathrm{o}}+\beta_{1} \Delta l_{n} \mathrm{RMP}+\beta_{2} \Delta l_{n} \mathrm{RC}+\beta_{3} \Delta l_{n} \mathrm{PCI}+$ $\beta_{4} \Delta l_{n} \mathrm{EXG}+\beta_{5} \Delta l_{n} \mathrm{LRQ}+\beta_{6} \Delta l_{n} \mathrm{LRP}+\beta_{7} \Delta l_{n} \mathrm{DSV}+$ $\beta_{8} \Delta l_{n} \mathrm{MaP}+\beta_{9} \Delta l_{n} \mathrm{MeP}+\beta_{10} \Delta l_{n} \mathrm{DD}-\lambda \mathrm{ECM}_{\mathrm{t}-1}+\mathrm{Vt} \quad(10)$

Where:

$\mathrm{ECM}=\left(\Delta l_{n} \mathrm{RMQ}_{\mathrm{t}}-\beta \mathrm{o}-\beta_{1} \Delta l_{n} \mathrm{RMP}-\beta_{2} \Delta l_{n} \mathrm{RC}-\right.$ $\beta_{3} \Delta l_{n} \mathrm{PCI}-\beta_{4} \Delta l_{n} \mathrm{EXG}-\beta_{5} \Delta l_{n} \mathrm{LRQ}-\beta_{6} \Delta l_{n} \mathrm{LRP}-$ $\left.\beta_{7} \Delta l_{n} \mathrm{DSV}-\beta_{8} \Delta l_{n} \mathrm{MaP}-\beta_{9} \Delta l_{n} \mathrm{MeP}-\beta_{10} \Delta l_{n} \mathrm{DD}\right)_{\mathrm{t}-1}$

$\lambda=$ Adjustment parameter which shows the extent to which the disequilibrium in the dependent variable $(\Delta \operatorname{lnRMt})$ is being corrected each period.

Where $\Delta=$ first deference operator and $\mathrm{Vt}=\Delta \mathrm{Ut}=$ $(\mathrm{Ut} \sim \mathrm{Ut}-1)$

Either equation (3) (if there is no long run relationship among the variables) or equation (10) (in the event of a long run relationship among the variables) shall be estimated.

\section{RESULT AND DISCUSSION}

From figure 2 we can deduce that per capita GDP and rice imports have direct relationship around 1970s per capita GDP rises and falls which also reflected in rice imports in same manner. Also around 1980s when there was a greater fall in per capita GDP probably due to economic depression there was also fall in rice imports. But from 1986s onward rice import does not show a significant response to change in per capita GDP. This is as a result of ban placed on rice from 1986 which was later lifted in 1996. From the graph (in Figure 3) around 1960s and early 1970 when exchange rate was relatively low and constant, rice import was very low. However: around 1980s rice importation was very low as a result of economic depression while exchange rate movement was linear. Furthermore from 1990s onward the change in rice imports and exchange rate cannot be compared. Therefore, it can be inferred from figure 3 that rice import and exchange rate are not correlated which indicates that rice importation into Nigeria is not discouraged by deregulation of the exchange rate. In fact when there was increase in exchange rate around 2006 and 2009 there was increase in rice imports which should be other way round. Figure 4 gives an indication of rice import quantity and its price within 1961 to 2013.

There is direct relationship between rice import quantity and rice import price. They are both correlated. According to what is been shown in figure 4 as rice import price increases rice import quantity also increases which support the law of supply that the higher the price the higher the quantity supplied or produced vice versa.

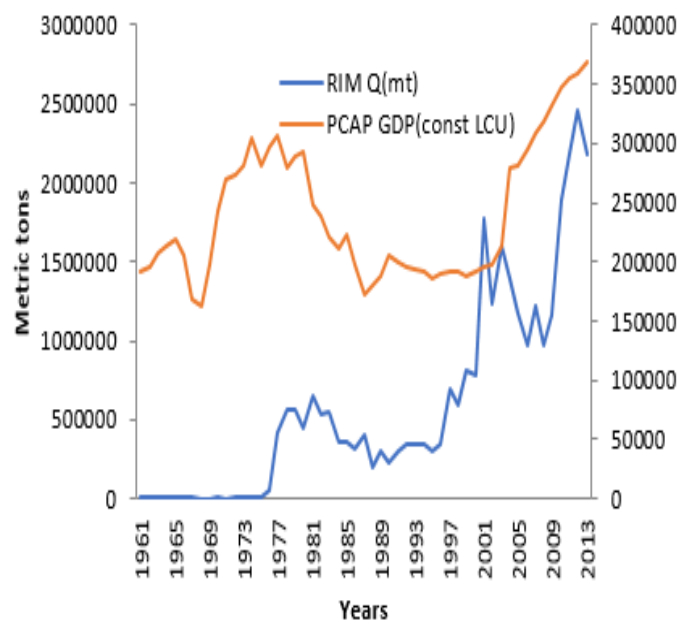

Fig 2: Trend in rice imports and per capita income in Nigeria between 1961 and 2013

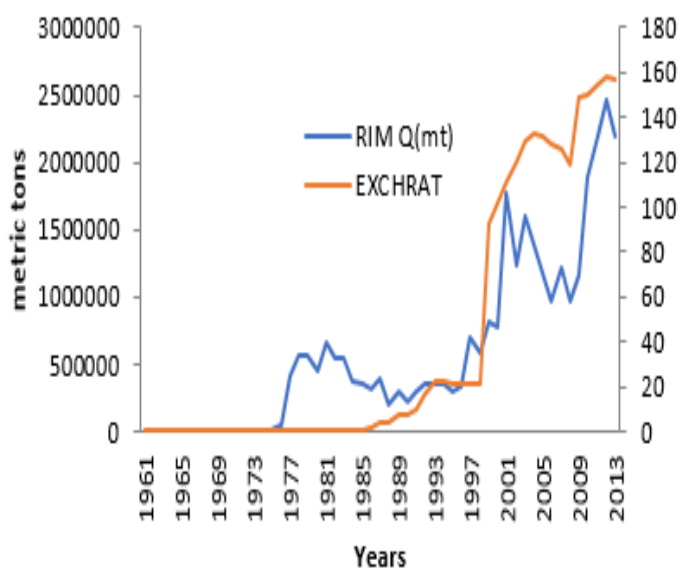

Fig 3: Trend in rice imports and exchange rate in Nigeria between 1961 and 2013 


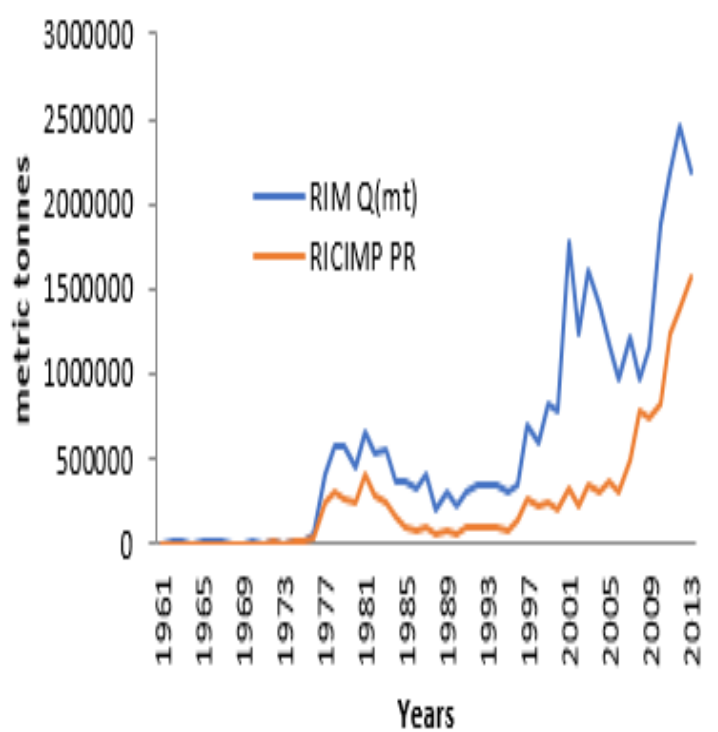

Fig 4: Trend in rice import quantity and rice import price in Nigeria between 1961 and 2013
Table 1 below indicates the order of integration of the variable in the model; this is in line with the primary requirement for interacting time series data. Unit root test shows that demographic development (DD) is integrated of order two I (2), domestic stock variation (DSV) is integrated of order zero I (0). All other variables were stationary at first difference. The result therefore affirms that the variables exhibit short run stability. Consequently, another diagnostic test was conducted to examine if there exist a long run relationship among the variables. This is shown in Table 2 for Johansen Cointegration Test. The result indicates that there exists a long run relationship among the variables. This is indicated by comparing the values of Trace statistics/Max. Eugen values with the critical values. The table reveals that there are at most four cointegrating equations. With this results, the variables were then interacted to determine the effects of each of the explanatory variables on the response variable. Table 3 indicates the result of error correction model (ECM). As expected, coefficient of error correction term ECT (-1) has negative sign and is statistically significant at 5\% level.

Table 1: Unit Root Statistics of the series

\begin{tabular}{|c|c|c|c|c|c|c|c|}
\hline \multirow[t]{2}{*}{ Variables } & \multicolumn{2}{|c|}{ ADF Test Results } & \multicolumn{2}{|c|}{ PP Test Results } & \multicolumn{2}{|c|}{ DF-GLS Test } & \multirow[t]{2}{*}{ Conclusion } \\
\hline & Level & 1st Diff. & Level & 1st Diff. & Level & 1st Diff. & \\
\hline RIMQ & -3.50 & -3.50 & -3.50 & -3.50 & -3.19 & -3.19 & I (1) \\
\hline Calculated Values & -1.66 & -4.44 & -1.97 & -9.81 & -1.73 & -4.52 & \\
\hline RIMP & -3.51 & -3.50 & -3.50 & -3.50 & -3.19 & -3.19 & $\mathrm{I}(1)$ \\
\hline Calculated Values & -2.85 & -3.71 & -1.84 & -8.49 & -2.03 & -3.76 & \\
\hline LRQ & -3.50 & -3.50 & -3.50 & -3.50 & -3.18 & -3.19 & $\mathrm{I}(1)$ \\
\hline Calculated Values & -2.60 & -9.69 & -2.48 & -10.54 & -2.41 & -7.11 & \\
\hline LRP & -3.50 & -3.50 & -3.50 & -3.50 & -3.18 & -3.19 & $\mathrm{I}(1)$ \\
\hline Calculated Values & -2.71 & -9.96 & -2.57 & -10.95 & -2.47 & -7.09 & \\
\hline $\mathrm{RC}$ & -3.50 & -3.50 & -3.50 & -2.92 & -3.18 & -3.19 & $\mathrm{I}(1)$ \\
\hline Calculated Values & -2.46 & -8.89 & -9.28 & -9.09 & -2.09 & -6.07 & \\
\hline PCI & -3.50 & -3.50 & -3.50 & -3.50 & -3.18 & -3.19 & $\mathrm{I}(1)$ \\
\hline Calculated Values & -0.90 & -5.12 & -1.22 & -5.07 & -1.09 & -5.20 & \\
\hline $\mathrm{EXC}$ & -3.50 & -3.50 & -3.50 & -3.50 & -3.18 & -3.19 & $\mathrm{I}(1)$ \\
\hline Calculated Values & -1.34 & -6.87 & -1.35 & -6.87 & -1.05 & -6.96 & \\
\hline MAP & -3.50 & -3.50 & -3.50 & -3.50 & -3.18 & -3.19 & $\mathrm{I}(1)$ \\
\hline Calculated Values & -2.00 & -7.46 & -2.08 & -7.46 & -1.80 & -7.47 & \\
\hline MEP & -3.50 & -3.50 & -3.50 & -3.50 & -3.18 & -3.19 & $\mathrm{I}(1)$ \\
\hline Calculated Values & -1.94 & -9.61 & -1.94 & -10.19 & -2.05 & -7.17 & \\
\hline DD & -3.50 & -3.50 & -3.50 & -3.50 & -3.19 & -3.19 & $\mathrm{I}(2)^{*}$ \\
\hline Calculated Values & -0.75 & -2.11 & 0.55 & -2.13 & -1.53 & -1.95 & \\
\hline DSV & -3.50 & -3.50 & -3.50 & -3.50 & -3.19 & -3.19 & $\mathrm{I}(0)$ \\
\hline Calculated Values & -4.59 & -11.73 & -4.86 & -12.90 & -4.69 & -12.00 & \\
\hline
\end{tabular}

Table 2: Johansen Test for Cointegration

\begin{tabular}{lllllll}
\hline Null & Trace & Critical & Prob & Max Eigen & Critical & Prob \\
Hypothesis & Statistics & Value at 5\% & Values ** & Values & Values at 5\% & Values ** \\
\hline $\mathrm{R}=0$ & 505.3879 & 334.9837 & 0.0000 & 94.93771 & 76.57843 & 0.0005 \\
$\mathrm{R} \leq 1$ & 410.4502 & 285.1425 & 0.0000 & 86.11368 & 70.53513 & 0.0010 \\
$\mathrm{R} \leq 2$ & 324.3365 & 239.2354 & 0.0000 & 77.80987 & 64.50472 & 0.0017 \\
$\mathrm{R} \leq 3$ & 246.5266 & 197.3709 & 0.0000 & 58.09530 & 58.43354 & 0.0539 \\
$\mathrm{R} \leq 4$ & 188.4313 & 159.5297 & 0.0005 & 47.26211 & 52.36261 & 0.1517 \\
$\mathrm{R} \leq 5$ & 141.1692 & 125.6154 & 0.0040 & 40.61015 & 46.23142 & 0.1768 \\
$\mathrm{R} \leq 6$ & 100.5590 & 95.75366 & 0.0224 & 34.98464 & 40.07757 & 0.1678 \\
$\mathrm{R} \leq 7$ & 65.57441 & 69.81889 & 0.1040 & 26.68475 & 33.87687 & 0.2806 \\
$\mathrm{R} \leq 8$ & 38.88966 & 47.85613 & 0.2647 & 15.19421 & 27.58434 & 0.7327 \\
$\mathrm{R} \leq 9$ & 23.69545 & 29.79707 & 0.2136 & 12.47710 & 21.13162 & 0.5013 \\
$\mathrm{R} \leq 10$ & 11.21834 & 15.49471 & 0.1984 & 8.662722 & 14.26460 & 0.3153 \\
$\mathrm{R} \leq 11$ & 2.555621 & 3.841466 & 0.1099 & 2.555621 & 3.841466 & 0.1099 \\
\hline \multicolumn{7}{c}{ Source: Output from E Views analysis } \\
\end{tabular}


This conformed to our observation under Johansen cointegration Test that there exist a long-run relationship between import demand and its independent variables. From the result rice consumption, price of meat, price of maize, local rice quantity, demography development and stock variance are statistically significant at 5\%. This implies that all these variables have impact on rice import demand either negatively or positively. While rice import price, per capita GDP, price of local rice and exchange rate are not statistically significant at $5 \%$ which implies that these variables have little or no effect on rice import demand. The probability of the null hypothesis being true is about zero. The Durbin Watson (having approximately 2) of the model confirms that there is absence of auto-correlation or serial correlation. The goodness of fit of the error correction model is very plausible. This indicate that the explanatory variables actually explain about 83 percent of the behaviour of rice import demand in Nigeria. The magnitude of each of the coefficient is however really high except for the exchange rate suggesting a higher effect of the explanatory variables except exchange rate which has smaller effect on the rice import demand in Nigeria. The signs of the coefficient of rice import price, per capita GDP, rice consumption, demography development, price of meat and price of maize are found to be positive while the signs of the coefficient of local rice quantity, local rice price, exchange rate, and domestic stock variance are negative. The positive signs of the coefficient of independent variables indicate that a unit change in any component of these variables will result in a positive change in the level of rice import demand. It could be observed that the sign of per capita income, rice consumption, exchange rate, local rice quantity, local rice price, maize price, demography development, and domestic stock variation conform to apriori expectation with theoretical belief while rice import price and price of meat does not conform to it. Thus the positive impact of rice consumption and per capita income implies that the higher they are the more the rice imports demand and vice versa. Also the Price of meat significant positive impact on rice import demand reveals that though rice and meat are assumed to be complement, an increase in price of meat does not affect the demand of rice import and its consumption. While the positive impact of Price of maize on Rice import demand support the assumption that they are substitute which means that as price of maize increases there would be increase in rice import demand and vice versa. But positive impact of rice import price on rice import demand does not support the law of demand which states that the higher the price of a commodity the lower the quantity demanded vice versa due to change in factors like population, per capita income etc. Also the negative influence of Local rice quantity on rice Import demand indicates that rice import demand and Local rice quantity are not moving along the same direction which implies that if local rice production is developed the rice import demand will reduce and vice versa. This is contrary to Ogundele (2007) finding, that output of local rice will not bring down importation. On the other hand the negative effect of Local rice price on rice import demand indicates that changes in local rice price may not necessarily determine rice import demand in Nigeria which corroborated with Ogundele (2007) finding that import demand for rice was inelastic with respect to price of Local rice. The Exchange rate negative impact on rice import demand implies that percentage increase in exchange rate will reduce the rice import demand though at a lower rate since the coefficient is very low (-0.014). This supports Sunday et al (2015) study that, the long run import demand function of rice respond negatively to exchange rate. The significant positive influence of demography development on rice import demand shows that as the population increases a rice import demand increase which is as a result of inability of local rice production to meet the increasing rice demand. Also the significant negative impact of stock variance supports the general belief that increments in domestic stock, ceteris paribus, should lead to a significant decline in volume of rice imports. Lastly, the error correction model is the most consistent determinant of imports. The relative importance attached to the various import policies by the authorities is reflected by the speed of adjustment measured by the coefficient of error correction term. The lagged ECM coefficient is significant, validating the error correction model specification. However the speed of adjustment of -1.97 is relatively high

Table 3: Result of the Nigeria's Error Correction Import Demand

\begin{tabular}{|c|c|c|c|c|}
\hline \multicolumn{5}{|c|}{ Model (1961-2013) } \\
\hline Variable & Coefficient & Std. Error & t-statistics & Prob. \\
\hline $\mathrm{C}$ & -0.520891 & 0.251489 & -2.071226 & 0.0493 \\
\hline DLRIMP(-1) & 0.701106 & 0.400637 & 1.749979 & 0.0929 \\
\hline DLRIMP(-2) & 0.691350 & 0.417442 & 1.656156 & 0.1107 \\
\hline DLRIMP(-3) & 0.107276 & 0.164517 & 0.652068 & 0.5206 \\
\hline DLPCAPGDP(-2) & 0.793206 & 1.167956 & 0.679140 & 0.5035 \\
\hline DLRCON(-1) & 1.687910 & 0.825780 & 2.044020 & 0.0521 \\
\hline DLRCON(-2) & 2.824729 & 1.013695 & 2.786568 & 0.0102 \\
\hline DLMEAT_PR2(-1) & 1.993187 & 0.687203 & 2.900436 & 0.0079 \\
\hline DLMEATPR2(-2) & 3.551745 & 0.826855 & 4.295486 & 0.0002 \\
\hline DLMEAT_PR2(-3) & 4.752395 & 1.123109 & 4.231466 & 0.0003 \\
\hline DLMAPR2(-2) & 0.489932 & 0.513072 & 0.954898 & 0.3491 \\
\hline DLMAPR2(-3) & 1.246528 & 0.480651 & 2.593414 & 0.0159 \\
\hline DLLOCRQ(-1) & -2.809752 & 0.910631 & -3.085500 & 0.0051 \\
\hline DLLOCRQ(-2) & 26.44202 & 26.08464 & 1.013701 & 0.3208 \\
\hline DLLOCRQ(-3) & -20.93397 & 16.82244 & -1.244408 & 0.2254 \\
\hline DLLOCRP2(-2) & -26.06868 & 25.65768 & -1.016019 & 0.3198 \\
\hline DLNLOCRP2(-3) & 21.95762 & 16.24526 & 1.351633 & 0.1891 \\
\hline DEXC(-3) & -0.014105 & 0.009148 & -1.541748 & 0.1362 \\
\hline $\mathrm{DD}(-2)$ & 9.931578 & 3.379828 & 2.938486 & 0.0072 \\
\hline $\mathrm{DD}(-3)$ & -9.703065 & 3.449642 & -2.812775 & 0.0096 \\
\hline DSTOCKVAR & $-1.05 \mathrm{E}-06$ & $3.71 \mathrm{E}-07$ & -2.828447 & 0.0093 \\
\hline DSTOCKVAR & $-6.48 \mathrm{E}-07$ & $3.93 \mathrm{E}-07$ & -1.647941 & 0.1124 \\
\hline ECT(-1) & -1.976364 & 0.420380 & -4.701371 & 0.0001 \\
\hline
\end{tabular}


Conclusion: From the results, increase in the level of demography development which leads to increase in rice consumption and a resultant increase in rice importation. Therefore, measures should be put in place to promote commercial farming (which would augment local rice production in large-scale and ensure efficient processing) such that the rice thus produced is affordable to consumers and guarantees a fair return to the producers. Also, policies and programmes with the ability and capacity to redirect and taste and preference of Nigerian's towards consumption of local rice should be adopted and carefully implemented, while rice import restriction policies be strengthened.

\section{REFERENCE}

Abubakar, S. (2013). Why Nigeria imports N1bn rice daily. DAILY TRUST http://allafrica.com/stories/201308080475.html

Akpan, S. B., Inimfon, V. P., and Samuel, J. U. (2014). Analysis of Monthly Price Transmission of Local and Foreign Rice in Rural and Urban Markets in Akwa Ibom State, Nigeria (2005 to 2013). Inter. J. Agric. Forestry, 4(1): 6-18.

Aliyu, S. R. (2001). Trade Liberalization and Economic Growth in Nigeria: 1970-1998. Unpublished Ph.D Thesis, Faculty of Social Sciences and Management Sciences, Bayero University Kano, Nigeria

Anyanwu, S. O., Ibekwe U.C., and Adesope O. M. (2010). Agriculture Share of the Gross Domestic Product and its Implications for Rural Development, Report and Opinion 2010, 2(8):2631

Bahmani-Oskooee, M. (1986). Determinants of international trade flows: The case of developing countries". Journal of development economics, 20: 107-123.

Bahmani-Oskooee, M., and Kara, O., (2003). Relative Responsiveness of Trade Flows to a Change in Prices and Exchange Rate; Inter. Rev. Appl. Econ. 17: 293-308.

Bamidele, F. S., Abayomi, O. O., and Esther, O. A. (2010). Economic analysis of rice consumption patterns in Nigeria. J. Agric. Sci. Tech. 12:1-11.

BigBen, C. O. (2016). Estimating Aggregate ImportDemand Function for Nigeria Revisited. IOSR Journal of Business and Management (IOSRJBM), 18(3): 64-72.
Cadoni, P., and Angelucci F. (2013). Analysis of incentives and disincentives for Rice in Nigeria. Technical notes series, MAFAP, FAO, Rome

Central Bank of Nigeria (CBN) (2006). CBN Statistical Bulletin

West Africa Rice Development Association (WARDA) (2001). Constraints, Opportunities and Strategic Choices Nigeria's Rice Economy: State of the Art by Bouake, Cote d'Ivoire, 2001. Countries, Macmillan London and Basingstoke

Daramola, B. (2005). Government policies and competitiveness of Nigerian rice economy. Paper presented at the 'Workshop on Rice Policy \& Food Security in Sub-Saharan Africa' Organized by WARDA, Cotonou, Republic of Benin.

David B., and Rita Mawuena F. (2015). Why the Persistent Increase in Ghana's Rice Imports? Prescriptions for Future Rice Policy. Asian J. Agric. Ext. Econ. Soc. 7(4): 1-21

Davis, D. R., and David E. W. (2002). An Account of Global Factor Trade", American Economic Review, 91: $1423-53$

Diako, C., Sakyi, D. E., Bediako A. B., Saalia, F. K., and Manful, J. T. (2010). Consumer perceptions, knowledge and preferences for aromatic rice types in Ghana; Nature and Science, 8(12): 12-19

Dornbusch, R. (2004). Expectation and exchange rate dynamic', Journal of Political Economy, reprinted in Dornbusch [1988 ed.] 'Open Economy Macroeconomics' NY: Basic Books Publisher during the DPRS Director's Conference held at NCEMA, Ibadan.

Edwards, S. (1989). Real Exchange Rates, Devaluation and Adjustment: Exchange Rate Policy in Developing Countries. MIT Press, Cambridge, Massachusetts

Egwaikhide F. O. (1999). Determinants of Imports in Nigeria: A Dynamic Specification. African Economic Research Consortium, (AERC) Research Paper 91.

Emodi, AI; Madukwe, MC (2011). Influence of Consumers' Socio-Economic Characteristics on Rice Consumption in South East Nigeria. Libyan Agric. Res. Cent. J. 2(3): 105-111

Erhabor, P., and Ojogho, O. 2011. Demand Analysis for Rice in Nigeria. J. Food Technol. 9(2): 66-74

Ezekiel, A.A., Adedapo, K.D; Olapade F. (2009). Technical efficiency of rice farmers in Ilesa 
agricultural zone in Osun State, Nigeria. Food production in a developing economy, 1: 220-204

FAOSTAT (2013). Agricultural production database. Food and Agricultural Organization of the United Nations, F.A.O. Rome, Italy.

Fashola, OO; Imolehin, ED; Wakatsuki, T. (2007). Water Management Practices for Sustainable Rice Production in Nigeria. Nig. Agric. Soc. J. 38: 42

Hemphill, (1974). The effects of foreign exchange receipts on import of less developed countries. IMF staff papers, 11

Houlhakker and Magee (1969). Income and price elasticities in world trade. Rev. Econ. Stat. 51: 111125.

Hyunsoo K; Lynn K. P; and Brian H. (2014). An Empirical Estimation of the Import Demand Model and Welfare Effects: The Case of Rice Importing Countries.

Ichoku H; Emea N. A; Ikpe M. 2013. Determinants of Nigeria's Non Oil Import Demand; South-Eastern Europ. J. Econ.1: 79-100.

Ikpe M. (2012). Determinants of Nigeria's Non-Oil Import Demand Import Demand: M.Sc. Project.

Isa, J. O; Cyprian, C. A; and Sam, O. O. (2012). Resource use efficiency and rice production in Guma Local Government Area of Benue State: An application of stochastic frontier production function. Intern. Rev. Soc. Sci. Hum. 3(1): 108-116

Jerome T. and Adenikinju A. F. (1995). Trade policies and the promotion of manufactured exports in Nigeria. Nigerian Economic Society (NES) Conference, Ibadan, Nigeria; 1-18

Juliano, O. (1985). Rice chemistry and technology; published by the American Association for Cereal Chemist, Inc. St. Paul Minnesota.

Junz H. B. and Rhomberg R.R. (1973). Prince Competitiveness in Export Trade among Industrial Counties. American Economic Review, Paper and Proceedings, Kano, Nigeria, 63: 412-418

Khan M.S. (1974). Imports and Exports Demand in Developing Countries. IMF Staff Working Paper, $21: 3$

Komolafe O. S. (1995). Modeling Imports Demand under Quantitative Trade Restrictions: An Application to Nigerian Data. J. Econ. Manage. 2: $55-77$
Kreinin M.E. (1967). Prince Elasticities in International Trade. Rev. Econ. Stat. 49: 510-516.

Nkang, M; Abang, S.O; Akpan, OE; Edet, EO (2006). Rice production, import and food security in Nigeria: An application of cointegration and error correction model. J. Food, Agric. Environ. 4(1): 86-90.

Mohamed, A. A. and Mohamed A. I. (2012). The Determinants of the Demand for Imports in GCC Countries. Inter. J. Econ. Fin. 4: 3.

Mohammad A. N. Nassr (2013). "Determinants and Econometric Estimation of Imports Demand Function in Palestine" The Islamic University of Gaza Deanship of Higher Education Faculty of Commerce Master of Economic Development, 2013

Mohammed, IS; Basiru, OF (2014). On the Stability of Nigeria's Import Demand: Do Endogenous Structural Breaks Matter? J. Rev. Global Econ. 2014, 3: 228-240

Moran, C (1989). "Imports under a foreign exchange constraint". The World Bank Economic Review, 3(2): 279-295

Morrison, TK (1984). Cereal imports by developing countries: Trends and determinants. Food Policy, 1984(1): 13-26.

Muhammad, IC; Zahid P; Amatul RC (2011). Determination of Import Demand in Pakistan: The Role of Expenditure Components. 8(561): 93-110

Narasimhan, B. and Pritchett, L. (1993). The Evolution of Imports Restriction in Sub-Saharan Africa in the 1980s: An Empirical Analysis. Working Paper Series, Centre for the Study of African Economies. Nigeria with the Trade Liberation Framework

Nigerian Tribune Newspaper (2004). "Nigeria Imported \$US700 million Rice in 2003 - Federal Minister of Agriculture and Rural Development: Adamu Bello, Monday 7th July.

Nkan, N. M; Abang, S. O; Akpan, O. E; Edet, E. O. (2006). Rice production, imports and food security in Nigeria: an application of error correction model. J. Food, Agric. Environ. 4(1): 86-90.

Obaniyi, KS; Akangbe, J. A; Matanmi, BM; Adesiji, GB (2014). Factors motivating incentives of farmers in rice Production training programmes A case study of Olam/USAID/ADP/First Bank Programme. J. Agric. Res. 2(5): 74 -81 
Ogundele F. (2007). Trade liberalization and import demand for rice in Nigeria: A dynamic modelling. J. Rural Econ. Dev. 16: 34-45.

Okeowo, T. A. (2016). Aggregate Import Demand Analysis of Rice in Nigeria 1970-2012. World Rural Observations 2016, 8: 3.

Okoh R. N. (2004b). Overview of the Nigerian economy and its management. A paper presented during the DPRS Director's Conference held at NCEMA, Ibadan.

Oluyemisi K. S., and Angga P. (2013). An Econometric Analysis of Rice Demand in Nigeria Paper presented at the $18^{\text {th }}$ annual conference on Econometric Analysis and Policy Challenges in Africa 24-26.

Omojimite B. and Akpokodje G. (2010). The Impact of Exchange Rates Reform on Trade Performance in Nigeria, Kamla-Raj.on Sustainable Rice Production in Nigeria organized by Central Bank of Nigeria held at Hamdala Hotel Kaduna from January 14-15, 2003.

Orcutt (1950). Measurement of Price Elasticities in International Trade. Rev. Econ. Stat. 32: 117-132.

Rahji, M. A. Y. (2005). Determinants of efficiency differentials in lowland rice production systems in Niger State, Nigeria. J. Agric. Res. 1(1): 7-17.

Olayide, SO (1968). Import demand model: An econometric analysis of Nigeria's import trade. Nig. J. Econ. Soc. Stud. 10(3): 303-319.

Rickard B. and St Pierre C. (2008). Examining trends and drivers of production and import demand for selected agricultural commodities. A Background Paper prepared for the International Food and Agricultural Trade Policy Council and the session titled "Changes in the structure of World Agricultural Production and Demand" at the Future of Agriculture: A Global Dialogue amongst Stakeholders. International Food \& Agricultural Trade Policy Council (IPC), Washington, D.C; 2008.
Sunday B. A; Glory E. E; and Inimfon V. P. (2015). Roles of Political and Economic Environments on Agricultural Commodity Import Demand in Developing Economy: A Case Study .of Rice SubSector in Nigeria. Inter. J. Econ. Fin. 7(12); 2015

Thirlwall, AP (1999). Growth and Development with Special Reference, Developing to Developing Countries, Macmillan London and Basingstoke

Udoh, EJ, Idiong, IC; Omonona, BT (2001). Determinants of food imports demand and policy shift in Nigeria (1960-1998). Inter. J. Soc. Sci. Public 2001, 4(2): 172-177

Uwatt, BU (1997). Import demand in Nigeria: A reexamination of the evidence. Nig. Finn. Rev. 2: 6586.

West African Rice Development Agency (WARDA), (1996): Rice trends in sub-Saharan Africa, Second Edition. WARDA, Bouaké. International Rice Research Institute (IRRI) (1990). Farm Level Constrains To High Yield in Asia. 1974-1977 IRRI, Los Banos, Philippines 123

Wilson and Takacs (1979). Differential Response to Price and Exchange Rate Influences in the Foreign Trade of Selected Industrial Countries. Rev. Econ. Stat. 61: 267-279.

Wudiri, BB; Fatoba, IO (1992. Cereals in the Food Economy of Nigeria in Lawani, S. M. and Babaleye, T. (eds.) Proceedings of the Workshop on Recent Development in Cereal Production in Nigeria, 2-4 September, Durbar Hotel, Kaduna.

Yekini, TK (1999). Determinants of Exports supply and the Demand for Imports in a Liberalized Economy. NISER Monograph Series, No. 28 Ibadan, Nigeria, 1-37. 